\title{
THE MOUNTAIN LAKE KIMBERLITIC PIPES OF NW ALBERTA: EXPLORATION, GEOLOGY AND EMPLACEMENT MODEL
}

\author{
Wood, B.D. ${ }^{1}$, Scott Smith, B.H. ${ }^{2}$, and de Gasparis, $\mathrm{S}^{3}$
}

1. Monopros Limited, P.O. Box 2520, Yellowknife, Northwest Territories, X1A 2P8, Canada

2. Scott-Smith Petrology Inc., 2555 Edgemont Boulevard, North Vancouver, British Columbia, V7R 2M9, Canada

3. Palynex Canada 2503 12th Avenue S.W., Calgary, Alberta, T3C 0S3, Canada

Introduction: Mountain Lake (ML) was the first occurrence of kimberlitic rock to be discovered in Alberta. The occurrence was found in 1990 by Monopros Limited, a subsidiary of De Beers Consolidated Mines Ltd. Mountain Lake is located $75 \mathrm{~km}$ ENE of Grande Prairie, Alberta, at the western margin of the interior planes of central Canada.

Exploration: Regional surface sediment sampling undertaken in the Peace River Arch area in 1988 identified concentrations of kimberlitic indicator minerals. Follow up work in 1989 indicated the main target was one small topographic high that was later confirmed to be anomalous by an airborne geophysical survey. Monopros recovered the first volcanic rocks from a hand dug pit in 1990 and subsequently conducted ground geophysical surveys as well as trenching, core drilling $(1750 \mathrm{~m}$, nine holes) and auger drilling to constrain the occurrence. Insignificant quantities of diamonds were recovered from trench and drillcore material, showing that this occurrence is uneconomic. ML contains low abundances of chromite, chrome diopside and garnet. The absence of G10 garnets and the rarity of spinels similar in composition to diamond inclusions, is consistent with the diamond results. In 1995 the Canadian and Alberta Geological Surveys completed two additional core holes (Leckie et al., 1997; also examined in this investigation).

Geological Setting: In the area of ML the Precambrian basement is covered by $>2500 \mathrm{~m}$ of Phanerozoic sediments including $>1000 \mathrm{~m}$ of relatively undisturbed Cretaceous sediments. Most of the sediments were deposited within the Western Interior Seaway, a broad shallow epicontinental sea with migrating shorelines. The ML kimberlitic rocks were emplaced into early late Campanian to Maastrichtian (Wapiti Formation) poorly consolidated sandstones, siltstones, shales and coal formations that formed in a non-marine flood plain or alluvial environment close to the western limit of the seaway during its last overall main regression. The basement in this area lies within the Chinchaga domain of the Rae Province. The Chinchaga formed in the Archaean at 2088-2186 Ma. but may contain older Archaean components.

Main constituents and rock types: The ML bodies are composed of extrusively formed volcaniclastic rocks with two main end member rock types: juvenile-rich and xenocryst- or quartzrich volcaniclastics. Gradations between the two end members are also present. The juvenile-rich volcaniclastics are dominated by altered olivine. Other coarse constituents include rare ultramafic and basement xenoliths. Magmatic selvages coat many of the coarser constituents, especially the olivines. Ubiquitous, but not abundant, small irregular to more rounded juvenile lapilli with no kernel $(<10-20 \mathrm{~mm})$ occur. The selvages and juvenile lapilli are composed of glassy to serpentine-like material. Some of the lapilli have vesicular textures. This material contains very fine perovskite, spinel, phlogopite, probable apatite and, relatively common, altered possible monticellite. Serpentine and carbonate occur in some lapilli but may be secondary. The compositions of the groundmass spinel ( $\mathrm{T} 1$ trend), perovskite and mica (9-14 wt. $\% \mathrm{Al}_{2} \mathrm{O}_{3}, \pm 1 \mathrm{wt} . \% \mathrm{TiO}_{2}, 4-8 \mathrm{wt} . \% \mathrm{FeO}$ ) are similar to phlogopites found in archetype kimberlites. The olivines, occurring both as single grains and 
within the juvenile lapilli, include anhedral and sometimes rounded macrocrysts $(<5 \mathrm{~mm}$ in size) and euhedral phenocrysts $(<1 \mathrm{~mm})$. Insufficient evidence could be obtained to apply a strict petrological classification. The observed features are similar to, but not totally characteristic of, kimberlites and there are no features indicating any alternative rock type. These rocks could represent a marginal or more extreme type of kimberlite and, are therefore, referred to as "kimberlitic". The inter-clast matrix is often indeterminate but appears to contain finely comminuted juvenile and clay-like material. The juvenile-rich volcaniclastics locally display bedding $(<1-2 \mathrm{~m}$ thick), which reflects variations in the size and abundance of olivine, xenoliths and the inter-clast matrix. Most bedding appears to be plane parallel and normally graded. Only minor xenocrystic quartz is present. Most of these volcaniclastics can be termed juvenile-rich, lapilli tuffs ( $>2 \mathrm{~mm}$ clast size) and coarse ash $(<2 \mathrm{~mm})$ or more simply olivine tuffs. In contrast, the xenocryst-rich volcaniclastics are composed mainly of medium-coarse sand sized grains of quartz $(<1 \mathrm{~mm})$. These rocks are poor in juvenile material including olivine and are structureless. Ultramafic and basement xenoliths and mantlederived xenocrysts are rare to absent.

Body size or morphology: The ML volcanics occur in at least two separate bodies, ML South and North (MLS and MLN respectively). MLS forms a pronounced topographic high that measures 400x600-700m ( 20 ha.). MLN has no topographic expression and measures about $250 \times 350 \mathrm{~m}$ ( 8ha.). Drilling indicates that MLS is steep sided $\left(\sim 70^{\circ}\right)$ and contains volcaniclastics down to at least $353 \mathrm{~m}$. The shape of MLN is less well established and volcaniclastics here occur down to at least $165 \mathrm{~m}$.

Internal geology: MLS is composed predominantly of juvenile-rich volcaniclastics. Bedding is well developed below $200 \mathrm{~m}$. MLN is composed of structureless quartz-rich, intermediate olivine-quartz, and partly bedded olivine volcaniclastics.

Sediments within and below the volcaniclastic rocks : Country rock sedimentary material is incorporated throughout the volcaniclastic rocks in both bodies but is seldom abundant. Small clasts of varied rock types occur (mostly $<1 \mathrm{~cm}$, up to $1-2 \mathrm{~m}$ ). These xenoliths consist of mainly mudstone, siltstone, sandstone and organic material including wood. Features such as very complex contacts, which include small scale mixing between the sediments and the host volcaniclastics, show that many of the sediment xenoliths were poorly consolidated when they were incorporated into the volcaniclastic rocks. Within the MLN volcaniclastics larger intersections of disturbed sedimentary material (up to $25 \mathrm{~m}$ ) that are not laterally continuous are interpreted as xenolithic blocks. In addition, up to $50 \mathrm{~m}$ of sediments were recovered from the drillholes below the volcaniclastics.

Palynology: The Campanian-Maastrichtian boundary has been identified in the country rock sediments at $515-530 \mathrm{~m}$ asl ( $200 \mathrm{~m}$ depth) at both MLS and MLN. The last marine sediments were deposited at an elevation of about $510 \mathrm{~m}$ asl. This sequence is consistent with the local stratigraphy and the overall upward regression leading to the cessation of the Western Interior Basin. The sediment xenoliths from within the volcaniclastics, notably including some from the same elevation as the surrounding in situ Campanian marine rocks, were derived from post Campanian, Maastrichtian terrestrial sediments. The volcaniclastic rocks from the two bodies yielded different palynological assemblages. The juvenile-rich volcaniclastics from MLS contain a rather uniform assemblage of non-marine Maastrichtian (or Campanian-Maastrichtian if results cannot be more time specific) microfossils. In contrast to MLS, most the samples of volcaniclastic material from MLN yielded not only Maastrichtian non-marine palynomorphs but also older marine micro-fossils derived from lower Cretaceous sediments. The nature of the palynomorphs in all of the volcaniclastic rocks indicates that 
they were very cool $\left(30^{\circ}-70^{\circ} \mathrm{C}\right)$ when they were incorporated into the volcanics. The palynology provides a maximum emplacement age for both bodies of mid-Maastrichtian, probably $68 \mathrm{Ma}$. and also shows that the volcanics erupted into a terrestrial deltaic environment with a tropical climate.

Emplacement model: The two ML bodies require contrasting emplacement models. MLS: The formation of this body is considered to be a two stage subaerial process : (1) pipe excavation with the deposition of most of the disrupted country rock material outside the crater, and (2) subsequent rapid pipe infilling predominantly by juvenile-rich volcaniclastics with minor dilution by country rock material, at least in part, by primary pyroclastic airfall processes. The presence of thinly bedded material suggests that some of the material was deposited into standing water such as a crater lake. No diatreme-facies or magmatic material was found. This general model is similar to that proposed for the Fort á la Corne (FALC) kimberlites in Saskatchewan (Scott Smith et al., this volume) which are interpreted as maars. In contrast to FALC rocks, the MLS volcaniclastics contain common fine material and armoured and accretionary lapilli suggesting wet subaerial eruption clouds. MLN appears to be a pipe formed by similar processes to MLS but it must have had a different infilling history to explain the much higher proportion of xenocrystic quartz, the common presence of older organic material, the lack of internal structure, and the presence of very large blocks of sediments within the volcaniclastics. It is most likely that the quartz and older palynomorphs were derived from the pipe wall. The thorough mixing of this material with juvenile volcaniclastic material in most, but not all, areas of MLN may result from processes other than pyroclastic ones. When contrasted to MLS, most of the features in MLN can be explained if much of the infilling resulted from secondary resedimentation processes of extra-crater deposits. Although there is no specific evidence to support the suggestion, many of the features could be explained if MLN was an open pipe when MLS erupted and that much of the resedimented and primary material was derived from MLS while MLN remained open. Some of the large deformed sediment blocks in MLN could be derived from the pipe-forming process and/or spalling of an unstable pipe wall. In contrast to the model presented here, Leckie et al. (1997) propose a different model: "that pyroclastic rocks were emplaced into and onto non-marine floodplain sediments of the Wapiti Group over a discrete time interval (<1Ma.). A positive relief volcanic feature was constructed on the floodplain" during the late late Campanian (between 75 and $76 \mathrm{Ma}$ ). The evidence presented here contradicts this model.

Conclusions: The ML pipes were the first kimberlitic rocks to be discovered in Alberta. Although the ML pipes were found to be uneconomic, they serve as an excellent case history of exploration and kimberlite emplacement within the Western Interior Basin. The mantle-derived magma type forming the ML bodies is not well established. If these bodies are composed of kimberlite it is a marginal or extreme variety and the term "kimberlitic" is applied to these rocks. The pipe-forming rocks are crater-facies juvenile-rich or xenocryst-rich volcaniclastics (probable tuffs and coarse ash). ML comprises at least two pipe-like bodies which have contrasting internal geology. The two main pipes were presumably excavated by similar processes, which may be maar-like, but were then infilled by different processes: one pipe was infilled mainly by primary pyroclastic material while secondary resedimentation processes may have dominated in the other. Exploration in this area has recently become very active with a new diamondiferous kimberlite field being discovered $350 \mathrm{~km}$ to the northwest of ML in the Buffalo Hills area.

\section{Reference}

D.A,.Leckie, B., Kjarsgaard, et al., 1997, Geology of a late Cretaceous possible kimberlite at Mountain Lake, Alberta - chemistry, petrology, indicator minerals, aeromagnetic signature, age, stratigraphic position and setting: Geological Survey of Canada, Open File 3441. 